\title{
The Behaviour of Wisent and Bison in Larger Enclosures
}

\author{
W. Jan Van Den BRINK
}

Brink Van den W. J., 1980: The behaviour of wisent and bison in larger enclosures. Acta theriol., 25, 11: 115-130 [Fig 9 Tables \& 2 Figs.].

The behaviour of small herds of European bison (=wisent) Bison bonasus ( $\mathrm{L}$ inna e u s, 1758) and American bison Bison bison Linna eus, 1758) in larger enclosures ( 2.2 and 0.8 ha respectively) is described, with special reference to use of available space and day rhythm. Some differences between the two species were found, which can be correlated with differences in way of life. The suitability of the enclosures is discussed.

[Leksmondhof 263, 1108 GA Amsterdam-Zuidoost, Netherlands].

\section{INTRODUCTION}

The bison, Bison bison ( $\mathrm{L}$ inn a e u s, 1758), and the European bison (or wisent, Bison bonasus (L inn a e s, 1758), are two closely related s species; their interrelationship has been amply discussed by Guthrie (1970) and G e is t (1971).

One of the most marked differences between the two species seems to be their habitat preference; apart from $B$. bison athabascae, now nearly extinct as "clear" subspecies, the bison prefers prairies, the wisent the woodlands. Many other differences, most of them anatomical and morphological, are summarized by Moh r (1939) and G e is t (1971).

Surely, both species belong to the more favourite zoo animals (the fact that the history of their near-extinction and rescue is well-known to the public may partly account for this), and therefore they are to be found in many zoological gardens. In 1974 the Artis Zoo, Amsterdam, got the opportunity of housing some animals in relatively large enclosures in the "Amsterdamse Bos", a 895 ha recreation area southwest of Amsterdam. The two adjacent enclosures, of which the wisent's is by far largest, cover together over 3 ha.

In this study the behaviour of the animals in these enclosures was observed in order to decide if they do behave naturally here, and from which an answer might be obtained to the question whether enclosures of this kind are suitable to the species. Secondly, the aim of the 
observations was to find out to what extent the available room is used, while in the third place the fact that two so closely related species were housed next to one another was a mere invitation to compare their behaviour in such circumstances.

P uce k (1967) emphasises the need for wisent research as relatively little is known of various aspects of the biology of this species. Among the problems to be investigated, summarized by $\mathrm{Pucek}$ (1967), he mentions the use of the habitat and daily activity rhythms, questions which are aims of this study as well. It is true that P uce k (1967) intended these problems to be studied on the free-living wisents of the Białowieża forest, but as the animals in the "Amsterdamse Bos " seem to live in more natural circumstances than is the case in usual zoo enclosures, it seemed justified to observe the animals with these questions in mind. One could say that these animals hold an intermediary position between the Białowieża and the zoo wisents, and the circumstances they live in could be compared e.g. with those in the National Park »Bayerischer Wald " in Federal Republic of Germany (K r i s c h k e, 1975),

It is hoped that this paper may give some insight in the behavioural characteristics of both Bison species under captivity conditions, as well as contribute to an appropriate construction of zoo enclosures for these animals.

\section{MATERIAL AND METHODS}

\subsection{Material}

The following animals were housed in the "Amsterdamse Bos during this study:

1. Wisent (Bison bonasus):

2105 Arno (M), born 9.8 .1967

1418 Aranda (F), born 3.2.1961

1981 Arsa (F), born 9.7.1966

2244 Arnita (F), born 12.11.1968

3034 Arwil (F), born 18.6.1973

Arborea (F), born 2.7.1975

All animals were born in the Artis Zoo, Amsterdam, except Arborea who was born in the "Amsterdamse Bos" enclosure; both Arwil and Arborea are daughters of Arsa. The numbers preceeding the names are the international studbook numbers; the number of Arborea was not yet known during preparation of the manuscript. 2. Bison (Bison bison):

Sam (M), born 12.5.1971

Rika (F), born 25.4.1958

Carla (F), born 7.7.1965

Nathalie (F), born 21.5.1971

Petra (F), born 12.4.1966 
All animals were born in the Blijdorp Zoo, Rotterdam, except Petra who is a daughter of Rika; Rika came to Artis on 1.4.1960. The three other animals first were sent from Rotterdam to the Noorder Dierenpark, Emmen, and came to Artis on 21.2.1975.

The wisents have been housed in the "Amsterdamse Bos" since June 1974, the bison came in April (Rika and Petra) and July (other animals) 1975:.

The enclosures of the animals are depicted in Fig. 1. The vegetation of the enclosures is mainly grass, with in some parts trees. The tree species are: in the wisent enclosure (sections W1 and W7) Fagus sylvatica and Quercus robur, with a few Quercus rubra and Acer campestre, and in the bison enclosure (sections B2 and B3) mainly Aesculus hippocastanum with some Fagus sylvatica, Quercus robur,

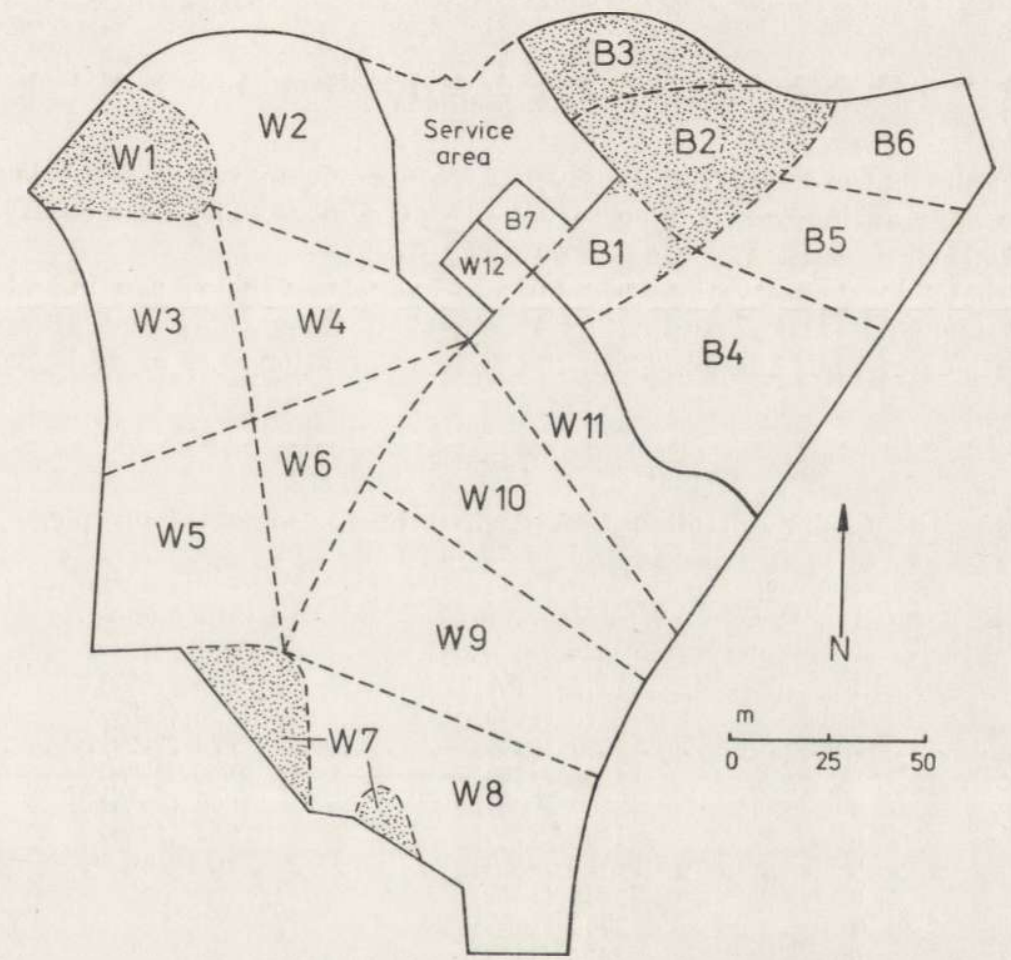

Fig. 1. Plan of the wisent and bison enclosures in "Amsterdamse Bos«, with subdivision as used in this study.

Sections W1-W12: wisent enclosure $(\mathrm{W} 12=$ stable), Sections B1-B7: bison enclosure $(\mathrm{B} 7=$ stable), Dotted areas indicate wood (tree sections).

Sections W1-W12: wisent enclosure (W12=stable), Sections B1-B7: bison enclosure the main undergrowth. Nearly all trees were fenced by barbed wire.

As can be seen from Fig. 1, the enclosure of the bison is relatively small (cf. Table 1). Therefore the bison had to be supplementary feeded, and hay is given in the sections B2 and B3. The wisents also received a small portion of hay daily, generally given in section W4.

During the day sections W12 (wisent) and B7 (bison), which each comprise the stables and a fore-court, are not open to the animals. At about 1530 to 1600 (on 
28.6.1976 at 1700) the animals got an additional food supply there and afterwards the stables were opened to them. So during the night the animals could stay indoors or outdoors at will. Next morning at about 0800, the animals were supplementary feeded again after which the animal keeper closed the entrance to the fore-court, and by doing so, access to the stables as well. At 4.7.1976, section W12 was open to the wisents during the 1530 observation only.

In the wood behind section W7 of the wisent enclosure a pair of roe deer (Capreolus capreolus), born in Artis, were housed, which could freely enter the wisent enclosure, appearing there mostly early in the morning and at sunset. The roe-buck sometimes was seen wfighting " with one of the wisents (on 16.61976 at 1400 with Arnita and on 25.6.1976 at 2030 with Arwil, a "fight « sometimes started by Arwil). A picture of Arno with both roe deer was published by Lensink (1976).

\subsection{Methods}

The animals were observed for seven days, every observation day being followed by two days during which no observations were made. The first observation day was 16.6.1976, consequently the last day was 4.7.1976.

On these days observations were made every half hour, starting at 0330, up to and including 2130 , resulting in 37 observations per day and alltogether 259 observations of each animal. Thus, the first observation was made before sunrise,

Table 1

Size of the sections (cf. Fig. 1) in sq. meters (multiples of $25 \mathrm{~m}^{2}$ ).

\begin{tabular}{|c|c|c|}
\hline Section Nr. & Wisent enclosure & Bison enclosure \\
\hline 1 & $1075(5 \%)^{*}$ & $625 \quad(8 \%)$ \\
\hline 2 & $2475(11 \%)$ & $1425(18 \%) *$ \\
\hline 3 & $2250(10 \%)$ & $900(11 \%) *$ \\
\hline 4 & $1575 \quad(7 \%)$ & $2550(32 \%)$ \\
\hline 5 & $2300(10 \%)$ & $1600(20 \%)$ \\
\hline 6 & $1450 \cdot(7 \%)$ & $975(12 \%)$ \\
\hline 7 & $725(3 \%) *$ & (stable) \\
\hline 8 & $2950(13 \%)$ & \\
\hline 9 & $2700(12 \%)$ & \\
\hline 10 & $2425(11 \%)$ & \\
\hline 11 & $2475(11 \%)$ & \\
\hline 12 & (stable) & \\
\hline Total & 22400 & 8075 \\
\hline
\end{tabular}

* tree section.

and the last one after sunset. Before 0330 and after 2130 it was too dark to discern the animals. I always arrived well before 0330 so that the animals were no longer disturbed by my arrival when I started observing.

Before this period observations were made during $11 / 2$ day as a try-out of the planned method, and to learn to recognise all animals individually.

The observations were made from the service area, with the use of a $8 \times 40$ binoculars. At each observation it was recorded where the animals were staying and 
what they were doing. Therefore the enclosures were subdivided in eleven (wisent) and six (bison) sections respectively (Fig. 1); it is true that these sections are differently shaped, but they now were well recognizable as such in the field. The sizes of the sections are given in Table 1.

Concerning the behaviour of the animals, five behavioural elements were distinguished, namely $f e=$ feeding (grazing, eating the additional food, and browsing); $s t=$ standing (without feeding); $w a=$ wa!king (without feeding); ly=lying (without feeding or ruminating); $r u=$ ruminating (mostly done whilst lying).

These elements exclude one another, although it seems that $l y$ and $r u$ alternate, so that these elements could perhaps be combined. The bison sometimes were seen ruminating whilst standing; this was recorded as st. If during an observation an animal showed more than one of the elements, only the most emphatic one was recorded, e.g. when standing (st) occurred for a moment during feeding (fe), this still was considered as fe. However, such situations did not often occur.

\section{RESULTS AND DISCUSSION}

When considering the results of this investigation, it should be kept in mind that the observations were made on animals living in the special circumstances of these particular enclosures, and also, that the collected data may be somewhat few to draw far-reaching conclusions, but at least some tendencies can be traced. The results are summarized in

Table 2

Percentages of occurrence in the same section at the same time for each pair of animals $(n=259)$.

\begin{tabular}{lclc}
\hline Animal pair & Average $\%$ & Animal pair & Average \% \\
\hline Wisent & & Arnita/Arborea & 77 \\
Arno/Aranda & 55 & Arwil/Arborea & 79 \\
Arno/Arsa & 48 & Bison & \\
Arno/Arnita & 58 & Sam/Rika & \\
Arno/Arwil & 52 & Sam/Carla & 54 \\
Arno/Arborea & $\mathbf{5 4}$ & Sam/Nathalie & 56 \\
Aranda/Arsa & 73 & Sam/Petra & 43 \\
Aranda/Arnita & 73 & Rika/Carla & 41 \\
Aranda/Arwil & 72 & Rika/Nathalie & 51 \\
Arand\%/Arborea & 72 & Rika/Petra & 61 \\
Arsa/Arnita & 71 & Carla/Nathalie & 63 \\
Arsa/Arwil & 73 & Nathalie/Petra & $\mathbf{4 5}$ \\
Arsa/Arborea & 82 & & 53 \\
Arnita/Arwil & $\mathbf{7 5}$ & & \\
\hline
\end{tabular}

Tables 2-9. Table 2 shows how often two animals were seen together in one section. For that purpose it was calculated from all observations how often a pair of animals found itself in the same section at the same time, expressed in percents. This table reveals a rather marked difference between both species: the wisent bull is seen much less in company of one of the cows than the cows among themselves, while 
the bison bull percentages are in the same order as the cows. The percentages of the bison are substantially lower than those of the wisent cows.

Table 3

Relationship between the time of day and presence at a specific section of the enclosure.

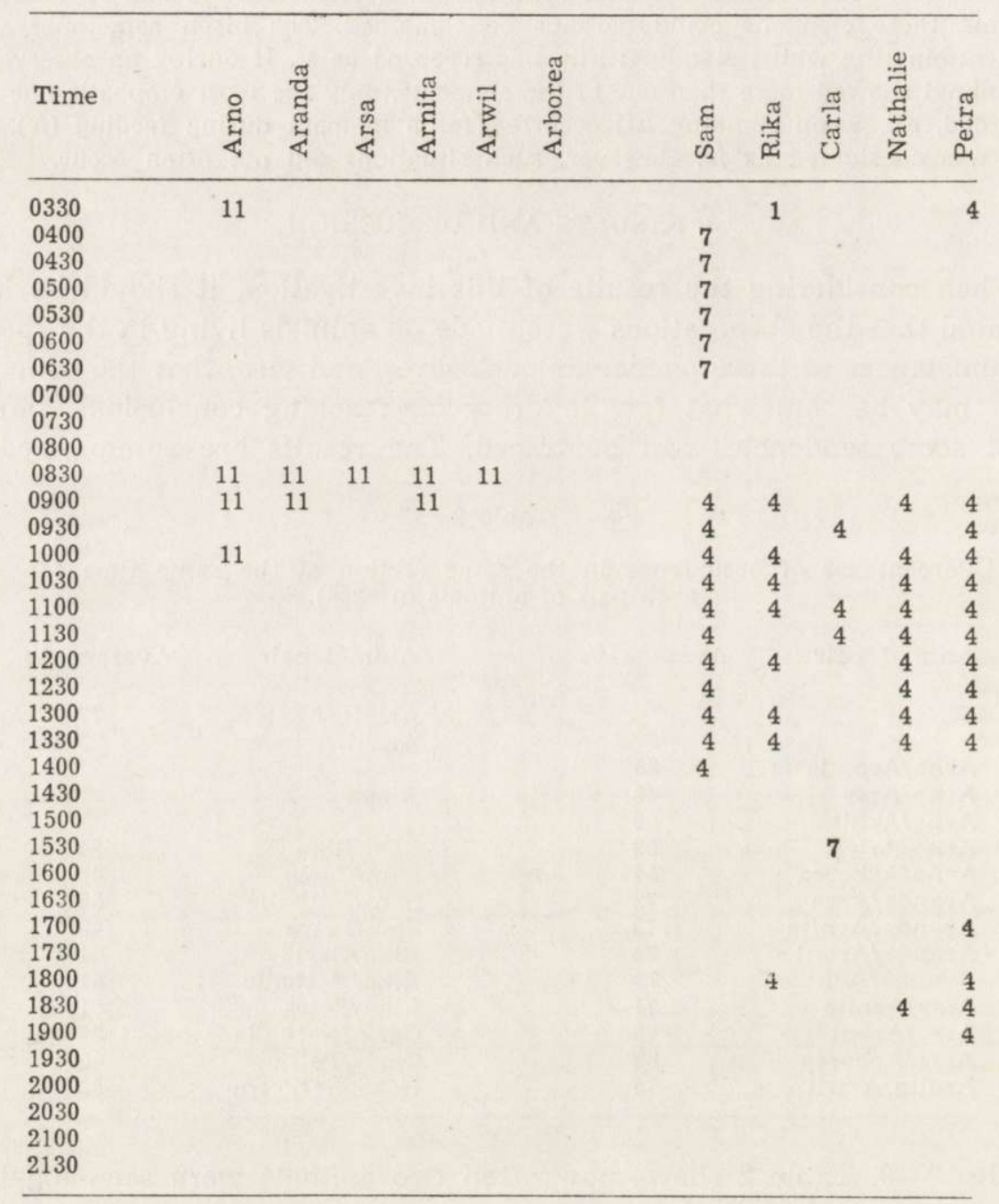

For the wisent, Krasinski (1967) writes that mature bulls are in the herds only during the mating season; they join the herds from late July until the beginning of October and migrate independently from the herds during the rest of the year. Also $\mathrm{M} \mathrm{o} \mathrm{h} \mathrm{r} \mathrm{(1952)} \mathrm{and} \mathrm{Kr}$ i s c h k e 
(1975) state that the wisent bull keeps a distance from the herd in summer.

On the other hand, M e a g h e r (1973) says that in the bison "mature bulls were commonly seen in the mixed groups at all seasons". H e c k (1968) only mentions that the bison bulls live somewhat apart from the herds during calving time (April-June), but according to Lott (1974) the bulls live solitary except during the mating season (July-August), although the bulls may join the herds in other times of the year as well. Thus, it seems that the separation between the sexes is less prominent in the bison than in the wisent, which is supported by the results of this study, although Krasins ki (1978) concludes that win the genus Bison separation of the sexes is not observed outside the rutting season".

It is tempting to discuss possible differences between the two species concerning the measure in which the herds do or do not congregate, but it should be considered, however, that there are so many differences in parameters on this point (number of animals, size of enclosures, number and size of sections, as well as "predictability" of presence in certain sections (Table 3 ) all differ in the two species) that it seems safer not to speculate much about this topic.

Table 3 shows the relationship between time of day and presence in a specific section of the enclosure. Presence in a section was considered to be connected with the time of day when on at least 5 out of the 7 days the presence of an animal was recorded in a specific section at a specific time. These results only, are summarized in the table.

Table 4 shows the relationship between the time of day and behavioural elements. It was drafted in the same way as described for Table 3: per animal only those behavioural elements, observed at least 5 times at a particular observation time, were included in the tabel. For this table the elements lying $(l y)$ and ruminating $(r u)$ were added together - which could be defended as mentioned in the previous chapter.

When Tables 3 and 4 are considered together, the following picture of daily routine of the animals can be formed: the wisents mainly graze in the early morning (particularly from 0400 till 0500) and in the evening hours, and also now and then in the course of the day. This is alternated sometimes by lying $(l y)$ and ruminating $(r u)$. Just after the additional feeding in the morning the animals can often be found in section W11.

The bison seem to become active somewhat later in the morning. From 0900 till 1330 the animals are generally found in section B4, while the bull almost always spent the early morning hours in the stable. Dur- 
ing that time they mostly show the elements lying $(l y)$ and ruminating (ru). From 0630 till 0830 , as well as in the course of the afternoon and the evening, they often show the element feeding ( $f e$ ), with a break for lying $(l y)$ and ruminating $(r u)$ between 1700 and 1800 .

\section{Table 4}

Relationship between the time of day and behavioural elements. Note: $l r$ means $l y$ plus $r u$.

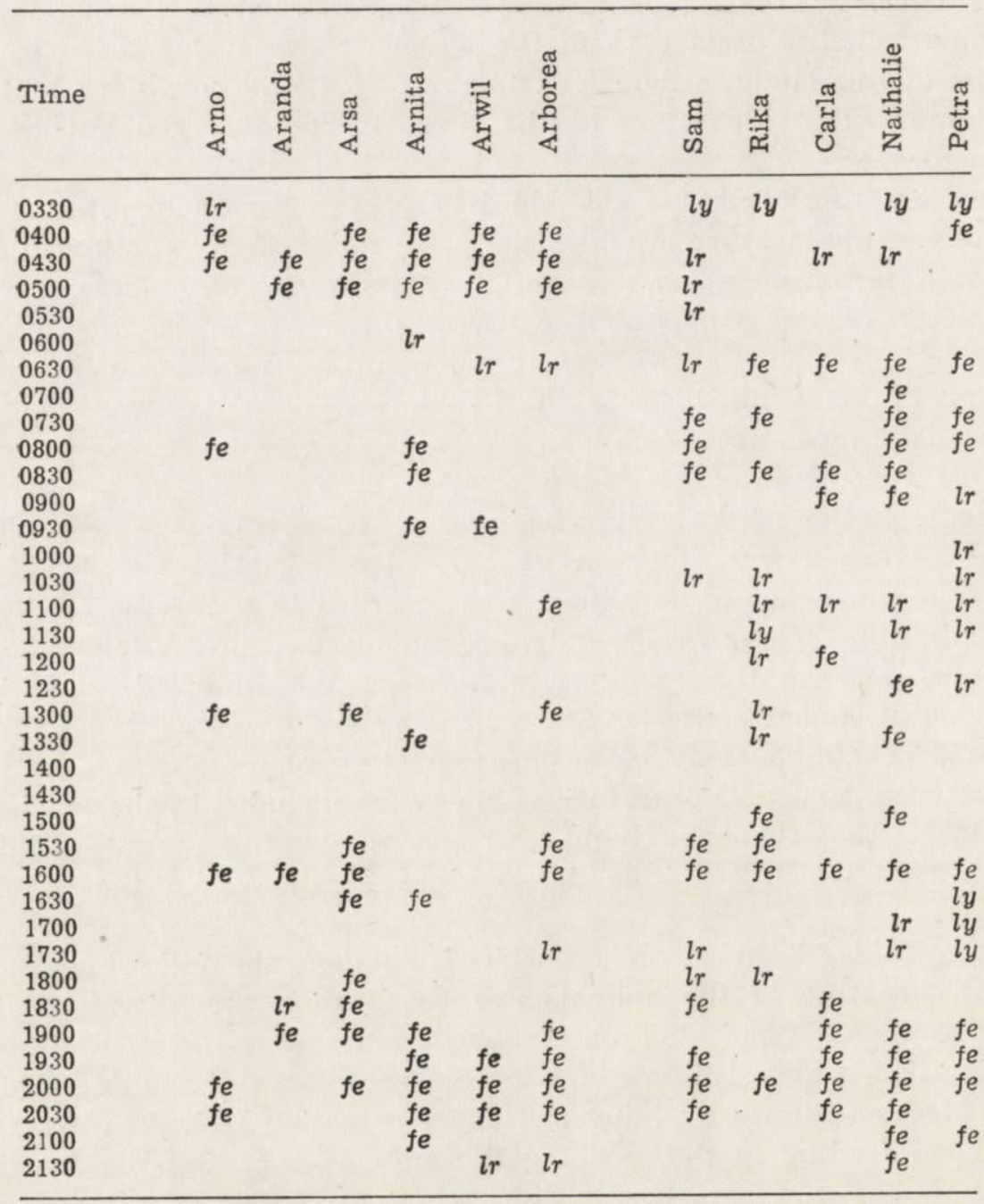

These observations can be compared with day rhythm of the wisents at Pless (=Pszczyna), as described by $\mathrm{M} \circ \mathrm{h} \mathrm{r}$ (1952), and the information given by $\mathrm{Krischke}$ (1975): the animals start grazing early in the 
morning, interrupted by a resting period. When it becomes hot, and the flies become active, the wisents retire among the trees; at dusk they reappear for grazing. $\mathrm{Ka} \mathrm{u} \mathrm{le} \mathrm{(1975)} \mathrm{only} \mathrm{mentions} \mathrm{greatest} \mathrm{activity} \mathrm{of}$ Białowieża wisents "in the morning and in the evening ".

Thus, these observations agree rather well with the results of this study; however, despite the very hot weather during the observation period, the retiring among the trees was not so obvious in the animals in the "Amsterdamse Bos", although the tree section W1 was quite popular with the wisents (cf. Table 5). On the other hand it seems that the animals can stand the sun better than $\mathrm{M}$ o $\mathrm{h} \mathrm{r}$ (1952) suggested.

Table 5

Presence of the animals in each of the sections on an average observation day, expressed in percentages per section for each animal.

\begin{tabular}{lrrrrrrrrrrrr}
\hline Section No. & 1 & 2 & 3 & 4 & 5 & 6 & 7 & $\mathbf{8}$ & 9 & 10 & 11 & 12 \\
\hline Wisent & & & & & & & & & & & & \\
Arno & 3.5 & 5.7 & 6.2 & 4.6 & 6.2 & 6.5 & 2.4 & 7.0 & 4.3 & 4.6 & 40.8 & 8.7 \\
Aranda & 12.4 & 8.4 & 7.0 & 7.0 & 2.7 & 3.8 & 9.7 & 5.4 & 6.2 & 7.0 & 24.1 & 6.3 \\
Arsa & 15.4 & 7.0 & 7.3 & 6.5 & 2.4 & 7.0 & 5.1 & 9.1 & 8.1 & 8.4 & 21.4 & 2.3 \\
Arnita & 11.9 & 9.7 & 7.0 & 7.3 & 4.6 & 3.8 & 2.7 & 6.5 & 3.8 & 7.8 & 28.6 & 6.3 \\
Arwil & 11.9 & 10.8 & 6.5 & 8.4 & 4.6 & 5.1 & 2.7 & 6.2 & 6.2 & 7.3 & 26.2 & 4.1 \\
Arborea & 13.8 & 7.0 & 8.9 & 7.0 & 3.8 & 5.7 & 3.0 & 8.1 & 5.4 & 7.0 & 24.3 & 6.0 \\
Average & 11.6 & 8.1 & 7.3 & 6.8 & 4.1 & 5.4 & 4.3 & 6.5 & 5.7 & 7.0 & 27.6 & 5.6 \\
Bison & & & & & & & & & \\
Sam & 10.0 & 6.5 & 4.6 & 34.1 & 8.9 & 5.4 & 30.5 & & & & & \\
Rika & 15.9 & 11.6 & 5.7 & 39.7 & 8.1 & 7.3 & 11.6 & & & & & \\
Carla & 13.5 & 5.7 & 5.4 & 37.0 & 10.0 & 7.3 & 20.8 & & & & & \\
Nathalie & 7.8 & 6.2 & 6.5 & 41.4 & 11.9 & 9.2 & 17.0 & & & & & \\
Petra & 11.9 & 13.2 & 6.2 & 51.4 & 6.5 & 2.7 & 8.1 & & & & & \\
Average & 11.9 & 8.6 & 5.7 & 40.8 & 4.2 & 6.5 & 17.6 & & & & & \\
\hline
\end{tabular}

Little has been published yet about day rhythm of the bison. As for the annoying flies, mentioned by $\mathrm{M}$ oh $\mathrm{r}$ (1952), it should be noted that M e a g h e r (1973) refers to »biting insect populations" as an important cause for large migrations of wild bison herds. Table 5 shows the number of times an animal was seen in each of the sections on one day (average of seven observation days); this frequency was expressed in percentages, and an impression of these frequencies may be gained from Fig. 2.

Although according to this table all sections are visited by all animals, some parts of the enclosures are still highly preferred. It is remarkable that for both species the section opposite the stables is most popular; on an average day the wisents spend $21-41 \%$ of their time in section W11, the bison even $34-51 \%$ in section B4. It should be noted that for the wisent cows section W1 comes on the second place, although it is relatively small (cf. Table 1), while the other tree section (W7) is much less frequented. 
For most bison section B7 (the stable) ranks second. They often stay there (cf. Table 7). It should be remembered in this respect that the stable is accessible only half of the day (cf. under 2.1. Material), so that it must be concluded that the bison regard the stable as quite attractive.

The fact that the wisents seem to have some preference for tree section W1 could be connected with the knowledge that this species lives in the woodlands. Krasinski (1978) reports, that more than $50 \%$ of all encounters with the animals in the Białowieża Primeval

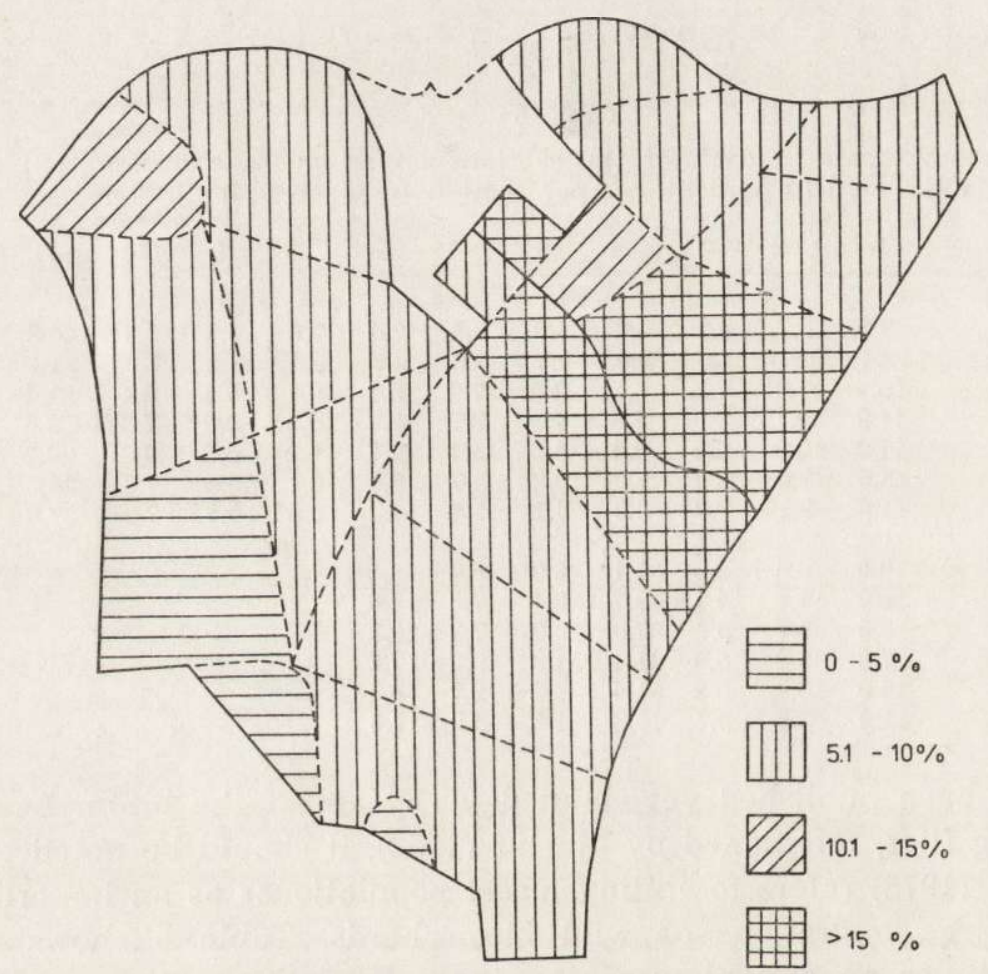

Fig. 2. Presence of the animals in each of the sections of their enclosures, expressed in percentages per section (average of 7 observation days, and of 6 wisents and 5 bison respectively).

Forest took place in wooded areas, mostly deciduous or mixed deciduous forest. It is true that the bison were also sometimes found in their tree sections (cf. Table 5), but it should be remembered that in these sections the additional hay is given, so that the animals must visit these sections perforce as it were. According to Table 7 the behavioura] element mostly observed in the sections B2 and B3 is in fact feeding $(f e)$. These considerations, together with the known habitat preferences 
of both species, can be seen as an indication that it might be justified to exchange both herds.

One could suppose that preference for certain sections of the enclosures is connected with the different sizes of the sections: the larger the section, the greater the chance an animal is found there. When the values of Table 5 are contrasted with the percentual size of the sections as given in Table 1, it becomes clear, however, that such a correlation does not exist except for the fact that section B4, which is by far the largest in the bison enclosure, is the most popular one as well. But it may be assumed that the section opposite the stable would also be frequented if much smaller, because obviously the area in front of the stable is Pavourite.

\section{Table 6}

\begin{tabular}{|c|c|c|c|c|c|}
\hline Animal & fe & st & $w a$ & $l y$ & $r u$ \\
\hline \multicolumn{6}{|l|}{ Wisent } \\
\hline Arno & 45.1 & 27.0 & 0.8 & 16.5 & 10.5 \\
\hline Aranda & 42.2 & 31.4 & 0.3 & 19.7 & 6.5 \\
\hline Arsa & 49.5 & 23.5 & 1.1 & 14.3 & 11.6 \\
\hline Arnita & 50.5 & 20.8 & 1.1 & 16.2 & 11.1 \\
\hline Arwil & 44.1 & 22.4 & 0.8 & 20.5 & 12.4 \\
\hline Arborea & 47.0 & 24.3 & 1.1 & 17.8 & 10.0 \\
\hline Average & 46.5 & 24.9 & 0.8 & 17.6 & 10.3 \\
\hline \multicolumn{6}{|l|}{ Bison } \\
\hline Sam & 41.4 & 13.2 & 5.1 & 22.7 & 17.8 \\
\hline Rika & 38.9 & 18.1 & 8.9 & 24.1 & 10.0 \\
\hline Carla & 48.9 & 17.8 & 11.1 & 10.8 & 11.1 \\
\hline Nathalie & 52.4 & 13.5 & 3.8 & 16.5 & 13.5 \\
\hline Petra & 47.8 & 9.7 & 5.1 & 21.9 & 15.4 \\
\hline Average & 45.9 & 14.6 & 6.8 & 19.2 & 13.5 \\
\hline
\end{tabular}

Table 6 gives the distribution of the behavioural elements on an average day (average of the seven observation days), for each animal. The figures represent (in percentages) the number of times the elements were observed on such an average day.

It is obvious from this table that there are no pronounced differences between the two species when the distribution of the five behavioural elements is compared, except that walking $(w a)$ seems to be somewhat more popular with the bison. This can be correlated maybe with their different way of life; according to A lle n (1876), cited by R o e (1972), the bison is quite nomadic in its habits. Migrations are necessary, as they normally live in large herds, which soon brings about a scarcity of food at one spot. As mentioned, M e a g h e $\mathrm{r}$ (1973) sees biting insects 
as an important cause. $\mathrm{R}$ o e (1972) discusses flies as a cause of wallowing; this behaviour by the way was seldom seen in the "Amsterdamse Bos« animals.

However, when the numbers of displacement as given in Table 9 are compared, both species show less prominent differences than might be expected from the Tables 6 and 7 . The reason is, that walking was mostly observed within one section (always non-stereotyped).

As appears from Table 9 the bison roughly show a number of displacement (movements) equal to that of the wisents, with the striking fact that for the bulls of both species the number is lower than for the cows. This should be combined with the fact that the bisons have less sections to go to, and that their presence in certain sections can more often be

Table 7

\begin{tabular}{|c|c|c|c|c|c|c|c|c|c|c|c|c|c|}
\hline Section & n No. & 1 & 2 & 3 & 4 & 5 & 6 & 7 & 8 & 9 & 10 & 11 & 12 \\
\hline \multicolumn{14}{|l|}{ Wisent } \\
\hline fe & (729) & 1 & 13 & 11 & 8 & 7 & 5 & 2 & 9 & 9 & 9 & 19 & 8 \\
\hline st & (\$76) & 23 & 1 & 0 & 2 & 0 & 1 & 12 & 1 & 1 & 1 & 48 & 10 \\
\hline$w a$ & (15) & 0 & 0 & 0 & 7 & 0 & 20 & 0 & 0 & 0 & 7 & 67 & 0 \\
\hline ly & (278) & 22 & 7 & 5 & 8 & 3 & 8 & 3 & 10 & 4 & 9 & 22 & 0 \\
\hline$r u$ & (156) & 13 & 6 & 13 & 11 & 2 & 11 & 1 & 4 & 4 & 10 & 26 & 0 \\
\hline \multicolumn{14}{|c|}{ Bison } \\
\hline fe & (595) & 4 & 16 & 12 & 31 & 16 & 13 & 8 & & & & & \\
\hline st & (187) & 27 & 4 & 1 & 20 & 2 & 0 & 47 & & & & & \\
\hline$w a$ & (88) & 39 & 14 & 2 & 31 & 5 & 0 & 10 & & & & & \\
\hline$l y$ & (249) & 11 & 0 & 0 & 67 & 6 & 1 & 16 & & & & & \\
\hline$r u$ & (176) & 10 & 0 & 0 & 64 & 1 & 1 & 24 & & & & & \\
\hline
\end{tabular}

Note: $f e=$ feeding, $s t=$ standing, $w a=$ walking, $l y=$ lying, $r u=$ ruminating.

predicted (cf. Table 3). Naturally it is not quite realistic to describe displacements as a move from one section to another: the sections as such do not exist for the animals of course. However, it seems the best way to describe the information obtained.

Table 7 shows behavioural elements in connection with sections of the enclosures. For this purpose recordings of all animals per species were added up (because the animals hardly showed any individual differences in this respect), and are expressed here as percentages per element.

The table gives interesting information concerning the use the animals make of the various parts of their enclosures. Feeding ( $f e$ ) is done by all animals in all sections (except for the wisent bull in section W1). All behavioural elements are shown in the most popular sections: 
W11 for the wisents and B4 for the bison; most elements are also observed more frequently in these sections than in any other. Here also the importance of the tree sections for the wisents becomes apparent again: except for section W11, standing is seen mostly in sections W1 and W7, and the same is true for the other resting element, lying, in section W1 (cf. Moh r, 1952). Walking, lying and ruminating was not seen at all in the stable. Walking was seen in section W11 and relatively often in section W6 as well; this is probably caused by the central position of this section which can be compared with section B1 in the bison enclosure where the same was observed.

As was mentioned before, the bison visit their tree sections primarly for food, and feeding is the most observed element here. The animals did not show lying or ruminating at all in these sections, and it seems

Table 8

Number of observations of the behavioural elements on June 19th (rainy day) and 28th (warm day).

\begin{tabular}{|c|c|c|c|c|c|c|c|c|c|c|}
\hline \multirow[b]{2}{*}{ Wisent } & \multicolumn{2}{|c|}{$\begin{array}{l}\text { fe } \\
\text { rainy warm }\end{array}$} & \multicolumn{2}{|c|}{ rainy warm } & \multicolumn{2}{|c|}{$\begin{array}{l}w a \\
\text { rainy warm }\end{array}$} & \multicolumn{2}{|c|}{ ryiny warm } & \multicolumn{2}{|c|}{$\begin{array}{c}r u \\
\text { rainy warm }\end{array}$} \\
\hline & & & & & & & & & & \\
\hline Arno & 17 & 11 & 9 & 15 & 0 & 0 & 7 & 7 & 4 & 4 \\
\hline Aranda & 20 & 10 & 9 & 23 & 0 & 0 & 6 & 2 & 2 & 2 \\
\hline Arsa & 20 & 12 & 8 & 14 & 0 & 0 & 7 & 6 & 2 & 5 \\
\hline Arnita & 22 & 15 & 6 & 13 & 0 & 0 & 6 & 5 & 3 & 4 \\
\hline Arwil & 18 & 12 & 7 & 13 & 0 & 0 & 8 & 6 & 4 & 6 \\
\hline Arborea & 21 & 12 & 7 & 13 & 0 & 0 & 6 & 9 & 3 & 3 \\
\hline $\begin{array}{l}\text { Average } \\
\text { Bison }\end{array}$ & 19.7 & 12.0 & 7.7 & 15.2 & 0 & 0 & 6.7 & 5.8 & 3.0 & 4.0 \\
\hline Sam & 16 & 15 & 4 & 5 & 6 & 3 & 2 & 11 & 9 & 3 \\
\hline Rika & 21 & 11 & 7 & 11 & 2 & 3 & 5 & 9 & 2 & 3 \\
\hline Carla & 18 & 19 & 8 & 5 & 2 & 6 & 2 & 4 & 7 & 3 \\
\hline Nathalie & 22 & 20 & 3 & 9 & 2 & 1 & 6 & 4 & 4 & 3 \\
\hline Petra & 17 & 16 & 5 & 3 & 3 & 1 & 4 & 9 & 8 & 8 \\
\hline Average & 18.8 & 16.2 & 5.4 & 6.6 & 3.0 & 2.8 & 3.8 & 7.4 & 6.0 & 4.0 \\
\hline
\end{tabular}

probable that they would seldom visit sections B2 and B3 when the hay would be given elsewhere. Most behavioural elements are observed particularly in the stable (in contrast to the wisents) and the sections opposite to it (B7, and B1 and B4 respectively); the other grass sections (B5 and B6) are visited almost only for feeding.

Table 7 gives the impression that the bison concentrates the various aspects of behaviour at a few spots in the enclosure, whereas for the wisent they can be observed throughout the entire enclosure. The bison thus seem to have more prominent "fix points" as described in general by $\mathrm{H}$ e diger (1961). One should not wonder that according to Table 7 walking $(w a)$ was not seen in all sections; wa was recorded only when 
tn animal walked up and down intensively, not when it just made a few steps, e.g. during grazing (cf. under 2.2. Methods).

Table 8 gives a comparison of the frequency of the behavioural elements on two of the observation days, namely June 19th and 28th, 1976. The first-mentioned day was the only rainy day during the observation period, while all other days were very beautiful and warm. Particularly the last five observation days were hot, with temperatures of $30^{\circ} \mathrm{C}$ or more, for Holland quite unusual. Of these days, June 28th was chosen at random in comparison with the rainy day.

From the table appears, that when it rains, the wisents do not seek cover among the trees, while the bison could be found relatively more in their tree sections on the rainy day. This supposition was supported also by later casual observations during rain. From the table it can be deduced that both species (although most pronounced in the wisent) showed more feeding and less standing on the rainy day, in comparison with the warm day. The other elements did not differ much, particularly

Table 9

Number of movements to other sections after first observation at 0330 (average of 7 observation days).

\begin{tabular}{llll}
\hline Arno & 17.7 & Sam & 17.6 \\
Aranda & 19.0 & Rika & 20.1 \\
Arra & 21.1 & Carla & 22.6 \\
Arnita & 19.3 & Nathalie & 21.1 \\
Arwil & 20.7 & Petra & 19.1 \\
Arborea & 20.9 & & \\
\hline
\end{tabular}

when lying and ruminating are combined. All in all, the influence of the weather, at least in summer, seems to be of little consequence. That the wisents do not hide among the trees when it rains, does not mean that they should seek cover from the sun; as stated above, the wisent apparently stand the heat quite well.

Finally, Table 9 gives the number of displacements (movements) during an average day. Each time an animal moved from one section to unother after the first observation at 0330 was noted down. E.g., an . animal that was seen in the sections $5,11,11,11,10,11,6,6,8$ respectively, moved 5 times. The table gives the average of the seven observation days for each animal. Table 9 was discussed already in connection with the discussion of Table 6 .

\section{CLOSING REMARKS ON ZOO ENCLOSURES}

Although it is somewhat difficult to base any conclusions on figures as collected in this study, it seems that the enclosures suit these animal 
species rather well. They appear to behave quite naturally here, compared to information in literature on free-living animals, although herd composition of the wisents, as well as mean group size, show some differences in comparison with that of the Białowieża animals as described by $\mathrm{Kr}$ a sins k i (1978). When additional feeding takes place, these enclosures seem to be large enough for these numbers of animals; e.g., the wisent bull can separate himself sufficiently from the cows.

These general remarks about the situation in the "Amsterdamse Bos" are made with one reservation: on account of the data of this report as well as the known habitat preference of the species, it might be justified to exchange both herds.

The importance of trees in an enclosure for wisents should be stressed unce again, the size of the enclosures seems to be somewhat less important, what can be deduced from the fact that just a few parts of the enclosures are used intensively. This last remark is made with some hesitation, for, of course, it does not mean that enclosures could be much smaller than they are now. On the contrary, it might, in general, be important to give zoo animals more room than strictly needed, but discussion of this subject is beyond the scope of this paper.

Acknowledgements: I thank the following persons who helped me in any way before, during, or after my observations: Dr. B. M. Lensink and Drs. D. Dekker (Artis, Amsterdam) and Prof. Dr. K. H. Voous and Dr. E. Nieboer (Free University, Amsterdam). I am also much indebted to $\mathrm{mr}$. F. Hooiveld, the animal keeper, as well as the "planting s section of the "Publieke Werken" service of the municipality of Amsterdam. Finally I am much obliged to three of my friends, my colleagues Dr. Jalb Schut and Dr. Robert Keller who critically read the manuscript and made valuable comments, and Miss Maina Huisken for correcting the English text of the manuscript.

\section{ADDITION}

After writing of the manuscript, the wisent and bison herds in the "Amsterdamse Bos « were exchanged, as is recommended in this paper on account of the observations that are reported here.

\section{REFERENCES}

1. Geist V., 1971: The relation of social evolution and dispersal in Ungulates during the Pleistocene, with emphasis on the Old World deer and the genus Bison. Q. Res., 1: 285-315.

2. Guthrie R. D., 1970: Bison evolution and zoogeography in North America during the Pleistocene. Q. Rev. Biol., 45: 1-15.

3. He ck H., 1968: Der Bison. Die neue Brehm-Bücherei, 378: 1-63.

4. Hediger H., 1961: Beobachtungen zur Tierpsychologie im Zoo und im Zirkus. F. Reinhardt: 1-430. Basel.

5. Ka ule G., 1975: Ferne Schutzgebiete nah gesehen: Białowieża. Nationalpark, 3-75: 22-25.

6. Krasiński Z., 1967: Free living European bisons. Acta theriol., 12: $391-405$.

9 - Acta Theriol... 
7. Krasiński $\quad$ Z., 1978: Dynamics and structure of the European bison population in the Białowieża Primeval Forest. Acta theriol., 23: 3-48.

8. $\mathrm{Kr}$ ischke N., 1975: Verhaltensbeobachtungen an Wisenten. Nationalpark, 4-75: $23-26$.

9. Lensink B. M., 1976: Dierentuinen en natuurbehoud. Panda Nieuws, 12: $39-41$.

10. Lott D. F., 1974: Sexual and aggressive behavior of adult male American bison (Bison bison). [In: "The Behaviour of Ungulates and its Relation to Management", eds: V. Geist \& F. Walther]. I.U.C.N. Publ. new series, 24, 1: 382-394. Morges.

11. Meagher M. M., 1973: The Bison of Yellowstone National Park. National Park Service Scientific Monograph Series, 1: 1-161.

12. Mohr E., 1939: Wisent und Bison, mit besonderer Berücksichtigung des Kaukasuswisents. Bijdr. Dierk., 27: 441-476.

13. M o hr E., 1952: Der Wisent. Die neue Brehm-Bücherei, 74: 1-75.

14. Pucek Z., 1967: The most important problems for further studies on European bison. Acta theriol., 12: 495-501.

15. R o e F. G., 1972: The North American Buffalo. A critical study of the species in its wild state. David \& Charles: $1-991$. Newton Abbot.

Accepted, July 12, 1979.

W. Jan Van den BRINK

\section{BEHAWIOR ŻUBRA I BISONA W ZAGRODACH}

\section{Streszczenie}

Opisano bahawior małych stad żubrów Bison bonasus (L innae us, 1758) 6 osobników i bizonów Bison bison (L inna e us, 1758) - 5 osobników w dużych zagrodach o wielkości 2,2 i 0,8 ha (Ryc. 1 ; Tabela 1 ), ze szczególnym uwzględnieniem wykorzystywania przestrzeni (Ryc. 2; Tab. 2) i rytmu dobowego (Tabele 3-6). Zagrody porośnięte byly głównie trawą, a w niektórych częściach również drzewami takimi jak klon, 2 gatunki dębów, buk i jesion. Stwierdzono występowanie pewnych różnic między omawianymi gatunkami zwierząt, które korelowały z różnicami związanymi z różnymi warunkami środowiskowymi specyficznymi dla tych gatunków (Tabele 7, 8, 9). 